\title{
Reinventing the Role of Academic Libraries in Nigeria to be Active Contributors to Student Wellness in the COVID - 19 Pandemic
}

\author{
AWALA-ALE, Isabella Idoefemu \\ Library Department, College of Education Warri, Delta State, Nigeria \\ DOI: https://dx.doi.org/10.47772/IJRISS.2021.5418
}

\begin{abstract}
Presently, there is a trend particularly in western nations where higher educational institutions are focused on supporting student wellness as an aspect relevant to the overall academic performance of its students. This trend is justified due to studies which highlight a correlation between student wellbeing (especially mental health) and the academic success of students. Interestingly, this trend contrasts with the situation in Nigeria. Nigerian academic libraries are yet to adopt policies wherein the library plays a crucial role in promoting student wellbeing. This article explores this problem and seeks to suggest methods adoptable by the Nigerian academic libraries in order to promote student wellness during and after the COVID19Pandemic.
\end{abstract}

Keywords: Students, Wellbeing, Nigerian, Academic libraries, COVID-19 pandemic, On-line education

\section{INTRODUCTION}

$\mathrm{P}$ resently, there is a trend particularly in western nations where higher educational institutions are focused on supporting student wellness as an aspect relevant to the overall academic performance of its students. This trend is justified due to studies which highlight a correlation between student wellbeing (especially mental health) and the academic success of students (Kirsti, Erik and Ottar, 2019). Interestingly, this trend contrasts with the situation in Nigeria (Aisha and Abdulrazaq, 2018); (Ebenezerand Kurokeyi, 2018). Reflective of this lack of focus on the wellbeing of students as an antecedent to student academic progress is the significant paucity of academic materials addressing the role Nigerian HEIs can play in promoting student wellbeing.

Although Nigerian HEIs have failed to take initiative and address the situation of student wellness (Adeyemi and Adeyemi, 2014); this does not represent an end to options. Academic libraries in Nigeria can take the initiative and provide innovative attempts at supporting student wellness. The position of the Nigerian academic library as the repository of academic information within HEIs should not limit its potential. Indeed, supporting student wellbeing is a task that is within the purview of all members of the HEI, the faculty, staffs and the library (Walton, 2018). As the "de facto centres of student life", academic libraries in Nigeria can lead the vanguard, influencing the Nigerian university into promoting a healthy campus which is necessary for student wellbeing (DeClercq and Cranz, 2014, p.1). This article seeks to suggest methods adoptable by the Nigerian academic libraries in order to promote student wellness during and after the COVID-19pandemic.

\section{HIGHER EDUCATION INSTITUTIONS AND STUDENT SUPPORT}

Internationally, there has been a notable change wherein HEIs increasingly function like businesses. Like businesses, there have been new driving forces which guide the actions of the administration, some of which includes competition for students, competition for research funds, high student expectations and internalization (Gül et al, 2010). These driving forces or goals can be directly linked to the performance of their current students. For instance, the success of their students invariably improves their reputation domestically and internationally (Cox, 2018). Improved domestic and international recognition provides an edge in the competition to attract students. Attracting more students is pertinent to the financial survival of HEIs.

This recognition of the role that the success of their present students can play in actualizing the goals of HEIs has invariably led to HEIs interested in monitoring and evaluating student experience with the aim of finding innovative ways to improve it (Atkinson, 2016). HEIs are now concerned with the whole lifecycle of the student, from admission to employment (Weaver, 2013). This was the premise of the research by LaFountaine et al (2006) when they argued that supporting student wellness is mutually beneficial to both parties because as universities ensure academic success and long-term development of healthy student behaviour, it will reflect positively on the HEI.

This situation above has led naturally to a focus on the development of healthy campuses. A healthy campus entails a place focused on supporting the whole student - a unified biopsycho-social entity (DeClercq and Cranz, 2014). Such healthy campuses are focused on promoting student wellbeing which can be understand using The World Health Organization's definition of wellbeing (2014), which is a state where "every individual realizes his or her own potential, can cope with the normal stresses of life, can work productively and fruitfully, and is able to make a contribution to her or his community." 
Promoting student wellbeing leads to the implementation of wellness programmes usually anchored to Hettler's (2018) interpretation of wellness wherein there are six dimensions that must be carted for before the whole wellbeing of the student is guaranteed. These six dimensions include: occupational, physical, social, intellectual, spiritual, and emotional wellness. Interestingly, some HEIs do not just subscribe to Hettler's (2018) six dimensions of wellness; they further modify it, adding their own contribution to what they believe consists of whole student wellness (Ramsey and Aagard, 2018).

Fulfilling Hettler's (2018) six dimensions of wellness requires a cross-institutional approach where all departments in HEIs deal with different aspects to ensure that the student experience is excellent. Libraries have a role to play in fulfilling student wellness (Atkinson, 2016). Subsequent sections will examine the traditional role of the Nigerian academic library and further initiatives they can take as part of their role in achieving student wellbeing during and after the COVID-19 pandemic.

\section{THE TRADITIONAL FUNCTIONS OF ACADEMIC LIBRARIES}

Identifying the academic library as an actor in promoting the wellbeing of students means a consideration of its traditional function as well as innovations it can make to ensure that it contributes to improving student wellness. Traditionally, the library has the aim of acquiring, organizing, preserving and providing access to information resources in all formats (Ferria et al, 2017). Libraries are sources of academic information, resources and research assistance to its users. With this purpose, libraries could be understood as integral elements of the HEI process due to their ability to provide a central location to information necessary for the working of HEIs (Li, 2006).

Interestingly, while these traditional functions have usually been geared towards meeting the academic needs of its users, academic libraries have inadvertently served as mediums via which student wellness can be improved (Wise, 2018). Indeed, academic libraries serve the function of being a safe space where students can have confidential access to information. The careful curation, organization and distribution of information provides a forum where students learn, thus assisting students as they develop their identity. This safe space is especially important in situations where students are attempting to navigate what could be taboo issues (Ramsey and Aargard, 2018).

\section{THE NIGERIAN ACADEMIC LIBRARY AND STUDENT WELLBEING}

The prior section has examined the importance of the traditional function of libraries and explored how academic libraries could inadvertently improve student wellness. However, the unintentional and inadvertent actions of the library should not limit innovativeness. Academic libraries in
Nigeria must be purposefully innovative in improving student wellness. Usually, libraries worldwide have developed based on what their users expected of them. For this reason, the response of individuals born generations apart when asked what the purpose of the library is will differ (Field and Tran, 2017). This should change because the library should not only rely on the responses of its users to be innovative. The Nigerian academic library must proactively address student wellbeing.

Focusing on the library can be rationalized when one considers the significance of the academic library within the academic community. Freeman (2005) described it as holding "...a central position as the heart of an institution-both symbolically and in terms of its physical placement. Preeminently sited and often heroic in scale and character, the library has served as a visual anchor for the surrounding buildings on campus" (2005, p.1). Exemplifying the expected innovativeness of Nigeria academic libraries is Penn State University library wherein its librarians utilized the use of Campus booth to share information (Ramsey and Aargard, 2018). Additionally, Stanford University installed a vending machine that dispensed the morning-after pill, condoms, and other sexual health products. This is a move that have inspired further actions by other universities which have taken the innovation to the next level by even positioning this vending machine in quite locations to ensure privacy and comfort when purchasing these health products (Ramsey and Aargard, 2018).The examples above are representative of innovations in USA and may not be replicable to Nigeria. However, they represent attempts by the library to ensure student wellness. However, there are several means which can be utilized by HEIs academic libraries and they shall be explored below.

\subsection{The Issue of Library Space: New and Innovative Services}

As it was stated earlier, the Nigerian academic library needs to be intentionalin its efforts to promote the wellbeing of its users through its management of the library physical space (Ramsey and Aagard, 2018); in the context of Hettler's six dimensions Wellness Wheel (Hettler, 2018). Concentrating on the issue of space is rationalized using the work of Awala-Ale (2006) who argued that as the heart of any academic institution, the functional academic library must be architecturally positioned to reflect the legacy and tradition of that institution.

Through the utilization of Hettler's Wellness Wheel (2018), with regards to the management of space (Awala-Ale,2006), attention must be paid to the fact that academic libraries in Nigeria are not just work places for students, they also serve as socializing stations (Oliveira, 2018). An implication is that the choice of furniture should reflect adaptability. The traditional furniture in Nigerian academic libraries is student carrels which are necessary for the traditional function of the library, for students who need isolation for research and study (Asaolu and Itsekor, 2014). However, there should also be consideration for those students whose preference is studying 
in groups. Indeed, Carlson (2005) found that the preferred learning method of students has increasingly shifted from isolated studying to group-learning and social interaction. Such considerations should entail the utilization of furniture which will be moveable and adjustable, thus allowing students to easily reconfigure the library space to fit their needs $(\mathrm{Li}$, 2006). The ability of Nigerian academic libraries to consider physical changes to its space to accommodate all types of learners will signify that Nigerian academic libraries are moving beyond its traditional tag as repositories of information and now embracing its function as a social hub bent on improving the wellbeing of its users ( $\mathrm{Li}, 2006)$.

Nevertheless, the change of the academic library space to address the social dimension of student wellness by accommodating all kinds of learners is not enough to ensure student wellness. Consideration of the furniture type could also address another aspect of student wellness, which is their physical wellness. Indeed, in the selection of library furniture, Nigerian academic libraries must consider the concept of ergonomics DeClercq and Cranz (2014). Such considerations are pertinent due to findings from research which reveals that sedentary behaviour and physical inactivity characterize student activity in the library and they pose a threat to student whole wellbeing (Dunlop et al., 2014). The typical impacts of the physical inactivity of library users includes changes in skeletal muscle, blood cholesterol, and lipid and glucose levels and the effects manifesting in levels in worse than in smokers and obese individuals (DeClercq and Cranz, 2014). With the above in mind, Nigerian academic libraries must not continue to contribute to the sedentary lifestyle of its users especially as a result of the built environments in HEIs which inadvertently promote sedentariness.

Nigerian academic libraries must create an environment that encourages movement which is a natural function of the human body. The Nigerian academic library must be adaptive, supporting movement and postural change (DeClercq and Cranz, 2014). Such a task will require the incorporation of stand-up desks as well as adjustable furniture which function in improving the posture of students as well as reducing stress, especially for students prone to working for long hours. Adoption of these body-conscious innovations that foster and encourage physical activity will reflect the decision of the Nigerian academic library to not be another sitting centered environment in the HEI environment. Hence, Nigerian academic libraries will subsequently become actively involved in promoting the wellbeing of its users (DeClercq and Cranz, 2014).

In addition, academic libraries can play a role in helping students achieve the amount of sleep necessary for them to function effectively (Wise, 2018). Such a consideration must not be taken lightly. In the Nigerian context, studies such as that of Seun-Fadipe et al, (2017) who conducted a study on the quality of sleep among 310 undergraduate students at a Nigerian University, recorded a significant number (48.0\%) of students who had poor sleep quality. Of that number, $77 \%$ recorded moderate to high level of perceived stress, with those students being at risk for psychopathology (Seun-Fadipe et al, 2017). The implications of the statistics above are that Nigerian academic libraries must make space for sleeping and resting within the library. The rationale for this is found from studies such as Wise (2018) who argued that libraries function as ideal locations for students to nap. This invariably improves the wellbeing of students because as increasingly stressed population characterized by sleep deprivation.

The ability of this suggestion to be considered is doubtful because there is a distinct lack of academic materials discussing the existence of napping areas in Nigerian academic libraries, thus reflecting how unimportant the issue is presently (Seun-Fadipe et al, 2017). Initiating this innovative function of the Nigerian academic library is even more necessary when one considers that library use among undergraduate Nigeria students is focused just in study and research. In the study by Folorunso and Njoku (2016), over $80 \%$ of 360 participants highlighted that they never used the library for relaxation or sleep.

Furthermore, Nigerian academic libraries must begin to offer the option of food in library spaces. In the past, the allowance of food in the library was prohibited and for good reason (Ajala et al, 2014). However, reconsidering this attitude is rationalized by its importance for student wellbeing. This should be norm in academic libraries. Indeed, by offering these spaces where students could take a break to eat, Nigerian academic libraries can provide spaces for "quick break and socializing" which McMullen (2008) notes is an essential characteristic of modern academic libraries (2008, p. $6)$.

\section{CORONAVIRUS (COVID-19) ANDON-LINE EDUCATION}

The COVID-19 pandemic, also known as the coronavirus pandemic, is an ongoing pandemic of coronavirus disease 2019 (COVID-19) caused by the transmission of severe acute respiratory syndrome coronavirus 2 (SARS-CoV-2), first identified in December 2019 in Wuhan, China. The outbreak was declared a Public Health Emergency of International Concern in January 2020 and a pandemic in March 2020. The first confirmed case in Nigeria was announced on 27 February 2020, when an Italian citizen in Lagos tested positive for the virus. On 9 March 2020, a second case of the virus was reported in Ewekoro, Ogun State, a Nigerian citizen who had contact with the Italian citizen (John Hopkins University, 2020).

Responding to the rapid spread of the Covid-19 virus, the Nigerian Government declared a national lockdown with the intent to reduce and contain the spread of the virus; closing all schools, including universitiesin March 2020. In June, according to Raimi(2020), "My University was closed as well, but the plans of switching to distance learning have failed to materialize. I have now spent over two months at home without being able to continue my studies online. I am sure 
many students across Nigeria are caught in the same dilemma which highlights the shortcomings of our educational system."

In the developed countries, the outbreak of the COVID-19 pandemic has necessitated the adoption of online education by Universities across the world (Czerniewicz, 2020) and the adoption of Emergency Remote Teaching (ERT) "as a temporary shift of instructional delivery to an alternate delivery mode due to crisis circumstances. It involves the use of fully remote teaching solutions for instruction or education that would otherwise be delivered face-to-face or as blended or hybrid courses and that will return to that format once the crisis or emergency has abated" (Hodges et al., 2020). Allen (2010) in "a survey on the use of social media in over 1200 libraries from across Europe reveals that $62 \%$ of respondents have 'positive' or 'very positive' views on social media" and observed Facebook, blogging, widgets such as RSS and microblogging as platforms used by libraries.

On the contrary, before the COVID-19 pandemic, the most popular social media tool used in Nigerian academic libraries was Facebook, followed by WhatsApp, (Adewojo andAdebara, 2016) as well as, You-tube and Instant Message (Adewoyin et al., 2017).Bakporhonor and Olise, (2015), emphasize that the major challenge librarians encounter in the use of social media for promoting library and information services were low level of technology penetration, network problem, lack of awareness and lack of funds. Anyaoku, Orakpor andEzejiofor (2012), affirm low knowledge in use the of Web 2.0 tools (e.g., Facebook, Twitter, Flickr, YouTube, etc.)by the librarians, and this was attributed partly to the absence or inadequate Internet connectivity. Erratic power supply, poor internet access, and inadequate ICT facilities were some of the constraints in the use of social media (Adewoyin et al., 2017). Davies et al. (2019), opines that poor technology infrastructure were barriersto execution of such projects as well as theft, low electricity supply, poor manpower engagement and total neglect (Gillwald et al., 2018).

Nonetheless, Nigerian academic libraries and librarians "must reject reference to them as mere custodians of knowledge and information in the national development process and should be part of the action centre in Nigeria's development efforts" (Awala-Ale, 2010). There is the need to integrate the traditional method of librarianship in our academic libraries with relevant ICT Infrastructure; "a librarian must possess the skills and knowledge necessary to employ the new digital technologies and information formats (Bell \& Shank, 2007). The social networks used by Nigerian libraries should include Facebook, YouTube, Blogging and WhatsApp, telegram, twitter and others for on-line education.

\section{SUPPORTING STUDENT WELLBEING IN THE UNIVERSITY LIBRARY: A CORE SERVICE OR A DISTRACTION?}

Theoretically, the idea of extending the functions of the Nigerian academic to cater also for student's wellbeing and on-line education is novel, noble and rational. By taking on some of these new functions and adapting its space, the Nigerian academic library is "creating the conditions for our students and staff to succeed" (Brewerton \& Woolley, 2016, p. 16). However, realistically, assuming new functions can create problems and create challenges (Walton, 2018).

A perennial challenge of libraries everywhere, including Nigerian academic libraries is budgetary constraints. It is always problematic to attempt to balance the need to meet new service expectations and the need to meet the traditional library functions ( $\mathrm{Li}, 2006)$. Thus, the idea of diverting some of these scarce funds into providing support for student wellbeing and on-line education will limit the academic libraries ability to fulfil its traditional functions.

Suggesting these innovative services for Nigerian academic libraries could naturally prove problematic because what could be considered as ordinary library services such as 24hours library opening and operation has not been a mainstay in Nigeria academic libraries. It has been recorded that the inability for Nigerian academic libraries to provide such rudimentary service is due to the strain it could put on existing library facilities and services due to a lack of library space, lack of library funds, as well as incidences of high staff turnovers in Nigerian academic libraries (Ajala et al, 2014).

Furthermore, it could be argued that a focus on improving student wellness can become a distraction, preventing the library from more noteworthy developments. In this present information age, the Nigerian academic library should be concerned with improving its resources, by migrating from print to electronic resources. However, by focusing on student wellness, the Nigerian academic library may not be able to fulfil this task. Questions can be asked of the necessity of improving the physical space of the library for the sake of student wellness and on-line education when the main aim of the academic library in this century a dedication should be to ensure that information is more accessible electronically ( $\mathrm{Li}$, 2006).

While the above argument holds water, it should be maintained that the library will always be indispensable as a base for learning and research. The digital age and the influence it will have on HEI approach to library design cannot take away the fact that the library will always be critical for students. Bennett (2005) in defending the importance of the library in the digital age argued that the success of the library is not linked to the frequency of use. Rather, success of the academic library should be anchored to the extent to which it can shape learning and transform its learners. This provides suitable justification for focusing on student wellness in the pandemic.

\section{CONCLUSION}

The symbolic position of the academic library as the heart of any institution entails that the library must continually strive to remain a dynamic force. The implication is that the library 
must always strive to support the academic community in diverse ways. The shift in the operational consideration of HEIs has impacted on the positioning of the library within the academic organization. While the library originally provides the function of connecting its users with resources, thus, functioning as the central hub in its contribution to institutional aims of impacting knowledge, the situation has changed with institutions no longer focused on just imparting knowledge but having other functions. The onus now rests with the librarians as members of the academic institution who seek new value and evolve. However, academic libraries can assume new roles of connecting users with services and space that can ensure students achieve wellness. Nigerian academic libraries need to assert their place as caregivers, contributing not just to the academic success of students but to the health and wellbeing of the students.

\section{REFERENCES}

[1] Adalf EM, Gliksman L, Demers A, and Newton-Taylor B (2001). The prevalence of elevated psychological distress among Canadian undergraduates: findings from the 1998 Canadian campus survey.J. Am. Coll. Health,50: 67-72.

[2] Adewojo A andAdebara O (2016). Social media usage by library staff in academic libraries: the Case of YabaCollegeof Technology, Lagos State, Nigeria. Information and Knowledge Management. 6(1): 43-49.

[3] Adewoyin OO, Onuoha UD, Ikonne CN (2017) Social media use and service delivery by librarians in Federal Universities in south-west, Nigeria. Library Philosophy and Practice.Available at:https://digitalcommons.unl.edu/libphilprac/1641(Accessed October 28, 2020)

[4] Adeyemi AM and Adeyemi SB (2014). Institutional factors as predictors of students' academic achievement in colleges of education in South western Nigeria. Academic Journals6(8): 141153

[5] Aisha D and Abdulrazaq AG(2018). Depression among students of a Nigerian University: Prevalence and academic correlates. Archives of Medicine and Surgery. 3(1): 6-10

[6] Ajala IO, Arinola AA, Adigun GO, and Ogunmodede TA. (2014) Extended hours in academic libraries: The experiences of three public universities in South Western Nigeria. American International Journal of Contemporary Research. 4(4):165-72.

[7] Anyaoku EN, Orakpor AM, Ezejiofor VO. (2012) Knowledge and use of Web 2.0 by librarians in Anambra state, Nigeria. African Journal of Library, Archives and Information Science. 22(1):31-40.

[8] Asaolu AO and Itsekor V (2014) Ergonomic Computer Workstation considerations for library Staff. International Journal of Academic Library and Information Science. 2 (3): 1-5

[9] Atkinson J (2016). 'Academic Libraries and Student Support. Quality and the Academic Library'. In Atkinson, J. (ed.) Quality and the Academic Library Reviewing, Assessing and Enhancing Service Provision(93-100). Cardiff: Chandos Publishing

[10] Awala-Ale II (2006). An Appraisal of University Library Buildings in Nigeria. Unpublished Doctoral Dissertation. Delta State University, Abraka.

[11] Awala-Ale II(2010). 'The Place of University Libraries in Integrated National Development' In Emman Osakwe (ed.) Social Studies and Integrated National Development in Nigeria (101-116). Kraft Books Limited.

[12] Bakporhonor B\&Olise F (2015). Challenges librarians encounter in the use of social media for promoting library and information resources and services in university libraries in South-South, Nigeria. International Journal of Humanities and Social Science. 5 (6): 208214.
[13] Bell SJ and Shank JD (2011) Blended librarianship: [Re]envisioning the role of librarian as educator in the digital information age. Reference \& User Services Quarterly. 51(2):105-110.

[14] Bennett S (2005), "Righting the balance". In Freeman, G.T. (ed.) Library as Place: Rethinking Roles, Rethinking Space. Washington, DC: CLIR

[15] Brewerton A and Woolley B (2016). Study happy: Library wellbeing initiatives from the University of Warwick. SCONUL Focus, 68: 1525

[16] Carlson S (2005), "The net generation goes to college", The Chronicle of Higher Education, 7 October, available at: http://chronicle.com/free/v52/i07/07a03401.htm(Accessed October 27, 2020)

[17] John Hopkins University (2020)COVID-19 Dashboard by the Center for Systems Science and Engineering (CSSE) at Johns Hopkins University $\quad(J H U)$ Available at https://gisanddata.maps.arcgis.com/apps/opsdashboard/index.html\#/b da7594740fd40299423467b48e9ecf6 (Accessed October 28, 2020)

[18] Cox J (2018) Positioning the academic library within the institution: a literature review, New Review of Academic Librarianship, 1-7

[19] Czerniewicz L (2020). What we learnt from 'going Online' during university shutdowns in South Africa. Available at:https://er.educause.edu/articles/2020/3/the-difference-betweenemergency-remote-teaching-and-online-learning(Accessed October $28,2020)$

[20] Davies IEE, Nwankwo CO, Olofinnade OM, and Michaels TA (2019)1st International conference on sustainable infrastructural development. IOP conf. series: Materials science and engineering. Insight review on impact of infrastructural development in driving the SDGs in developing nations: A case study of Nigeria

[21] DeClercq CP and Cranz G (2014). Moving Beyond Seating-centered Learning Environments: Opportunities and Challenges Identified in a POE of a Campus Library. The Journal of Academic Librarianship, 40(6): 574-584

[22] Ebenezer Aand Kurokeyi EP (2018). Mental health status of students attending tertiary institutions in Bayelsa State, Nigeria. Journal of Public Health and Epidemiology. 10 (10): 363-369

[23] Ferria A, Gallagher BT, Izenstark A, Larsen P, LeMeur K, McCarthy CA \& Mongeau, D (2017). What are they doing anyway? Library as place and student use of a university library. Evidence Based Library and Information Practice, 12(1): 18-33.

[24] Field N and Tran R (2018) Reinventing the public value of libraries. Public Library Quarterly, 1-15

[25] Freeman GT (2005) "The library as place: changes in learning patterns, collections, technology, and use". In Freeman, G.T. (ed.) Library as Place: Rethinking Roles, Rethinking Space. Washington, DC: CLIR

[26] Folorunso O. and Njoku E. (2016) Influence of Library Environment and User Education on Undergraduates' Use of Library at the University of Ibadan, Nigeria. European Scientific Journal 12 (19): 288-304

[27] Gillwald A, Odufuwa F and Mothobi O. (2018) The state of ICT in Nigeria. Research ICT Africa. 3(5):1-118.

[28] Gül H, Gül SS, Kaya E and Alican A (2010) Main trends in the world of higher education, internationalization and institutional autonomy. Procedia Social and Behavioral Sciences 9: 1878-1884

[29] Hettler, B. (2018) "The Six Dimensions of Wellness." National Wellness Institute. Available athttps://www.nationalwellness.org/page/Six_Dimensions

[30] Hodges C, Moore S, Lockee B, Trust T and Bond A. (2020) The difference between emergency remote teaching and online learning. Available at:https://er.educause.edu/articles/2020/3/the-differencebetween-emergency-remote-teaching-and-online-learning(Accessed October 28, 2020)

[31] Kirsti G, Erik RS, andOttar B (2019). Mental Health, Academic SelfEfficacy and Study Progress Among College Students - The SHoT Study, NorwayFront Psychol.10: 45.

[32] Li X (2006). Library as incubating space for innovations: practices, trends and skill sets. Library Management, 27(6/7): 370-378

[33] Oliveira SM (2018). Trends in Academic Library Space: From book boxes to learning commons. Open Information Science, 2(1): 59-74 
[34] Raimi JA (2020). How I Experienced Nigeria's National Lockdown.AfricademicsJune 10, 2020. Raimi Joseph Abidemi is a student at the University of Lagos and represents Africademics as a University Ambassador.

[35] Ramsey E and Aagard MC (2018). Academic libraries as active contributors to student wellness. College \& Undergraduate Libraries, $1-7$

[36] Seun-Fadipe CT, Mosaku K, Komolafe M, Fawale A and Adebowale A (2017) 1123 Sleep Quality, Perceived Stress and Academic Performance of Undergraduate Students in A Nigerian University. Sleep, 40 (1): A418-A419
[37] Walton G (2018) Supporting Student Wellbeing in the University Library: A Core Service or a Distraction? New Review of Academic Librarianship, 24(2): 121-123

[38] Wise MJ (2018). Naps and Sleep Deprivation: Why Academic Libraries Should Consider Adding Nap Stations to their Services for Students. New Review of Academic Librarianship, 24(2):192-210

[39] World Health Organisation. (2014). Mental health: A state of wellbeing. Available at: http:// www.who.int/features/factfiles/mental_health/en/ 